\title{
Do We Need Gastric Acid?
}

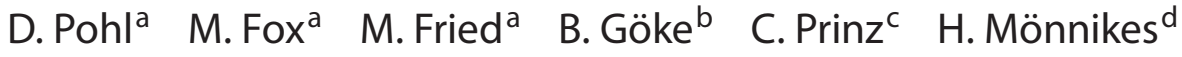

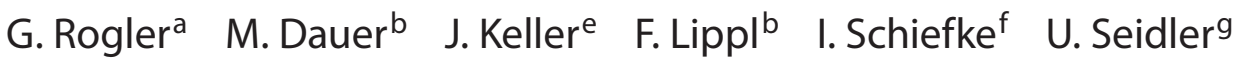 \\ H.D. Allescher ${ }^{h}$ on behalf of the Kandahar Study Group
}

\begin{abstract}
a Division of Gastroenterology, Department of Internal Medicine, University Hospital Zurich, Zurich, Switzerland;
bSection of Gastroenterology, Department of Internal Medicine, Campus Innenstadt und Großhadern, University of Munich, and ' Medical Department, Technical University of Munich, Munich, ${ }^{\mathrm{d} D i v i s i o n}$ of Hepatology, Gastroenterology, and Endocrinology, Department of Medicine, Charité Medical Center, Campus Virchow,

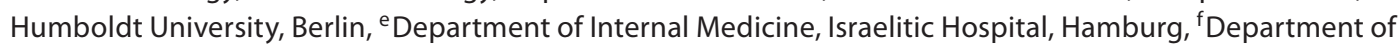
Internal Medicine, University Hospital Leipzig, Leipzig, ${ }^{9}$ Department of Gastroenterology and Hepatology, Medizinische Hochschule Hannover, Hannover, and h Center for Internal Medicine, Gastroenterology, Hepatology and Metabolism, Klinikum Garmisch-Partenkirchen, Garmisch-Partenkirchen, Germany
\end{abstract}

\section{Key Words}

Gastric acid secretion • Gastric emptying • Gastric motility • Helicobacter pylori · Clostridium difficile · Proton pump inhibitors · Acid suppression - Metabolism, neuroendocrine • Ghrelin · Satiety

\begin{abstract}
Evidence from comparative anatomy and physiology studies indicates that gastric acid secretion developed during the evolution of vertebrates approximately 350 million years ago. The cellular mechanisms that produce gastric acid have been conserved over the millennia and therefore proton pump inhibitors have pharmacological effects in almost all relevant species. These observations suggest that gastric acid provides an important selective advantage; however, in modern-day humans the need for gastric acid can be questioned in light of the widespread use of safe and effective pharmacologic acid suppression. The Kandahar Working Group addressed questions concerning the need, production and effects of gastric acid, specifically: (1) motility in the upper gastrointestinal (GI) tract; (2) neuroendocrine factors; (3) digestive and mucosal processes; (4) microbiology, and (5) central processes and psychological involvement. We ad-
\end{abstract}

\section{KARGER \\ Fax +41613061234 \\ E-Mail karger@karger.ch}

www.karger.com
(C) 2008 S. Karger AG, Basel 0012-2823/08/0774-0184\$24.50/0

Accessible online at: www.karger.com/dig dressed each topic with the individual models available to answer our questions including animal versus human studies, pharmacologic, surgical as well as pathophysiologic states of acid suppression. Copyright $\odot 2008$ S. Karger AG, Basel

\section{Introduction}

Evidence from comparative anatomy and physiology studies indicates that gastric acid secretion developed during the evolution of vertebrates approximately 350 million years ago. The cellular mechanisms that produce gastric acid have been conserved over the millennia and therefore proton pump inhibitors (PPIs) have pharmacological effects in almost all relevant species. These observations suggest that gastric acid provides an important selective advantage; however, in modern-day humans the need for gastric acid can be been questioned in light of the widespread use of safe and effective pharmacologic

This review is based on the proceedings of the Kandahar Workshop, 22-25 June 2006, Grainau, Germany. The meeting was supported by an unrestricted educational grant by Altana-Nycomed.

Daniel Pohl, MD

Division of Gastroenterology and Hepatology

Department of Internal Medicine, University Hospital Zurich

Raemistr. 100, CH-8091 Zurich (Switzerland)

Tel. +41 44255 1111, Fax +41 44255 4591, E-Mail daniel.pohl@usz.ch 
acid suppression. The Kandahar Working Group addressed questions concerning the need, production and effects of gastric acid, specifically: (1) motility in the upper gastrointestinal (GI) tract; (2) neuroendocrine factors; (3) digestive and mucosal processes; (4) microbiology, and (5) central processes and psychological involvement. We addressed each topic with the individual models available to answer our questions, including animal versus human studies, pharmacologic, surgical as well as pathophysiologic states of acid suppression.

\section{Gastric Acid and Motility}

The effect of gastric acid on gastric motility and emptying has been neglected in the recent literature. Moreover many 'established facts' are based on small, shortterm observational studies in healthy volunteers or in animal models. Four central issues concerning the interaction of gastric acid and function are addressed in this review, namely the effects of (1) acid instillation in the stomach and small bowel, (2) patho-physiologic states of acid secretion, (3) pharmacologic and (4) surgical acid suppression.

\section{Acid Instillation in the Stomach and Small Bowel}

Early animal studies have shown a dose-dependent delay of gastric emptying after instillation of organic acids (i.e., an inverse relationship between gastric emptying rate and hydrogen ion concentration). Increasing the molecular weight of the organic acids also inhibited gastric emptying; however, increasing the instilled volume accelerated the process [1]. More recently, Holzer et al. [2] confirmed that instillation of physiologic concentrations of hydrochloric acid delayed gastric emptying in a rat model, an effect that was blocked by atropine, suggesting involvement of a vagal mechanism.

The effects of small bowel acid exposure on gastric emptying are also inhibitory. Lin et al. [3] used a dog model in which they exposed different lengths of small bowel with different concentrations of acid. A dose-dependent inhibition of gastric emptying was demonstrated. This effect increased as longer segments of small bowel were exposed to acid; however, no effect was observed beyond the proximal $150 \mathrm{~cm}$ of jejunum. Other authors reproduced these findings and demonstrated that vagotomy attenuates the effects of gastric acid instillation on motility [4].

Although acid receptors in the stomach may inhibit gastric emptying directly, these studies suggest that the inhibitory effect of acid on gastric emptying is mediated by $\mathrm{pH}$ receptors in the proximal small bowel $[4,5]$. This effect probably serves to maintain neutral $\mathrm{pH}$ for efficient small bowel digestion. Given the large volume of gastric acid secretions (1.5-2.5 liters/day), efficient feedback mechanisms are mandatory to ensure effective buffering of acid leaving the stomach and the appropriate interaction between gastric and small bowel function.

\section{Pathophysiologic States of Acid Secretion}

It has been shown that gastric emptying is delayed in patients with atrophic gastritis compared to healthy controls [6]. In this condition plasma levels of gastrin are inversely related to gastric emptying and, consistent with this finding, patients with residual acid secretion have faster emptying rates than those with achlorhydria [6]. However, the effect of gastrin on gastric function is not straightforward because in patients with chronic hypergastrinemia, such as the Zollinger-Ellison syndrome, no consistent changes in gastric emptying are seen [7]. This paradox may be explained by the effect of gastrin on secretion volume. Classic studies by Hunt and Stubbs [8] have shown that large volumes empty from the stomach faster than small volumes. In atrophic gastritis elevated levels of gastrin represent a feedback response to decreased gastric secretion from diseased mucosa, whereas in Zollinger-Ellison syndrome pathological levels of gastrin from a neuroendocrine tumor drive excessive gastric secretion. Thus, in these pathophysiologic states, the effect of gastrin on gastric emptying may be counteracted by changes in gastric secretion volume. This explanation is supported by a study that showed that replacement of gastric secretions (including acid and pepsin) normalized emptying and improved trituration of solid foods in patients with atrophic gastritis [9].

\section{Pharmacologic Acid Suppression}

In the fasted state, acid suppression increases phase 3 migrating motor complex (MMC) activity ('housekeeping contractions' that clear the bowel of undigested debris), whereas stimulating gastric acid secretion decreases MMC activity $[10,11]$. This is likely due to alkaline $\mathrm{pH}$ in the duodenum triggering this contraction pattern [10].

In the fed state, most (but not all) studies show that acid suppression with $\mathrm{H}_{2}$-receptor antagonists $\left(\mathrm{H}_{2} \mathrm{RA}\right)$ and PPIs delays gastric emptying of solid food, although effects on liquid food are less consistent [9, 12-15]. Interestingly the delay in solid emptying is associated with vigorous antropyloroduodenal (APD) contractions (with- 
out a change in peristaltic frequency) [16]. It has been suggested that the combination of increased APD activity and delayed gastric emptying indicates poor coordination of antral contraction with pyloric opening. However, it is also possible that acid suppression impairs chemical digestion and more vigorous mechanical breakdown of solid foods is required before gastric contents can pass through the pylorus $[9,17]$. As in atrophic gastritis, pharmacologic acid suppression leads to hypergastrinemia $[18,19]$. Studies have shown that intravenous infusion of gastrin increases antral activity and delays gastric emptying [16]. Moreover reduced gastric secretion volume on $\mathrm{H}_{2} \mathrm{RAs}$ or PPIs would also be expected to slow gastric emptying [11]. However, the relative importance of acid suppression on secretion volume and motility with regard to gastric emptying is unknown.

\section{Surgical Acid Suppression}

In contrast to pharmacologic acid suppression, the effects of highly selective vagotomy on the gastric body (i.e., denervating the parietal cells but sparing the pylorus) in patients with peptic ulcer disease has been subject to long-term follow-up with regards to gastric motility and acid suppression [20-22]. Delayed gastric emptying is common in the early post-operative period; however, gastric function normalizes in the majority of patients at repeat testing after 6-12 months [20,21], an effect that is maintained for at least 10 years despite a sustained reduction in basal and stimulated acid output [22].

\section{Summary}

Gastric acid has effects on upper GI functions in animal models and healthy volunteers. Acid-sensitive receptors provide feedback regulation that prevents the passage of excess gastric acid into the small bowel and maintains a $\mathrm{pH}$ environment conducive to efficient digestion. In disease states as well as pharmacologic studies, reduced acid secretion appears to delay gastric emptying; however, it is difficult to differentiate the effects of secretion volume and acid production on this process, and the clinical importance of this observation remains uncertain. Firstly, it has not been established that this effect is associated with symptoms of gastric retention or clinically relevant maldigestion. Secondly, no long-term follow-up data has been published. Although surgical procedures such as highly selective vagotomy may have direct effects on gastric function that delay emptying, it is interesting to note that these return to normal within a year. Thus, at least in the post-operative state, there appear to be compensatory mechanisms that can normalize gastric emptying despite a sustained reduction in gastric acid secretion. Similarly, the effects on gastric emptying and motility are reproducible in different states of acid suppression but have not been shown to be clinically relevant and seem to be compensated in the mid- to longterm. Further studies are required to address whether patients experience symptoms directly or indirectly related to delayed gastric emptying during pharmacologic acid suppression, and to assess whether gastric function returns to normal over time.

\section{Neuroendocrine Regulation of Gastric Acid Secretion}

Cranial, Gastric and Postgastric Secretory Responses

Gastric acid secretion is subject to a complex regulation by endocrine, paracrine and neurocrine mediators that interact extensively. Even before ingestion, the sight and smell of food leads to acetylcholine release from vagal nerve fibers that stimulates acid production via stimulation of $\mathrm{M}_{3}$ receptors on parietal cells and also, indirectly, by increasing histamine release via acetylcholine receptors on the surface of ECL cells. Intragastric distension and an increase in luminal $\mathrm{pH}$, together with certain nutritional factors (e.g., calcium), further promote gastric acid secretion via release of gastrin from antral G cells. Gastrin mediates its stimulatory action on parietal cells mainly via the blood stream and induction of histamine release from ECL cells in the proximal stomach, but also has a direct stimulatory effect on parietal cells via cholecystokinin (CCK-B) receptors. This alternative pathway is probably of minor physiological importance. The most important physiological inhibitor of gastric acid secretion is somatostatin secreted by antral $\mathrm{D}$ cells in response to low intraluminal $\mathrm{pH}$. This inhibits gastrin release and gastric acid secretion directly via receptors on parietal cells and indirectly by inhibiting histamine secretion from ECL cells. In humans CCK is a potent stimulant for somatostatin release acting via CCK-A receptor, thereby inhibiting gastrin secretion [23]. Another potent inhibitor of gastric acid secretion is secretin. Its release is stimulated by duodenal acid and the effect is also mediated mainly by somatostatin $[24,25]$. Numerous other neurohormonal peptides involved in the GI response to feeding, including GIP, GLP-1, GLP-2, PYY, VIP, galanin and GRP also regulate gastric acid secretion via actions on gastric G, ECL and D cells, respectively [26-33].The effects are largely inhibitory and exerted via central feedback. 


\section{The Effect of Ghrelin on Gastric Secretion}

This review focuses on the effects of recently discovered enterohormones on gastric acid secretion, in particular ghrelin, an orexigenic peptide produced to $80 \%$ by the gastric oxyntic mucosa (X/A cells), but to a minor degree also in the central nervous system [34,35]. Ghrelin accelerates gastric emptying in experimental animals and humans by inducing 'fasting' type $3 \mathrm{MMC}$ activity [36]. The role of ghrelin in the regulation of gastric acid secretion is accepted; however, interpretation of findings is difficult as its effects are dose dependent and vary with the mode of delivery [37-44]. Following intravenous application $[5-20 \mu \mathrm{g} / \mathrm{kg}(\hat{=} 1.5-6 \mathrm{nmol} / \mathrm{kg})$, molecular weight of ghrelin: $3,314 \mathrm{~g} / \mathrm{mol}$ ] in rats, stimulation of gastric acid secretion was observed which was almost equipotent to histamine ( $3 \mathrm{mg} / \mathrm{kg}$ i.v.). The anticholinergic atropine and cervical vagotomy, but not an $\mathrm{H}_{2}$-receptor antagonist inhibited this effect [40]. Similarly, whereas relatively low doses of intraperitoneal ghrelin [5-80 $\mu \mathrm{g} / \mathrm{kg}(\hat{=} 1.5-24$ $\mathrm{nmol} / \mathrm{kg}$ )] increase gastric acid output [43], high doses of ghrelin (1-30 nmol/kg i.v.) given to rats with chronic gastric fistula or subcutaneously $(1-10 \mathrm{nmol} / \mathrm{kg})$ had either no effect on gastric acid output or inhibited acid output [41]. The central effects of intracerebroventricular ghrelin on gastric acid secretion are dose dependent and inhibitory at low doses $(0.1 \mathrm{pmol} / \mathrm{rat}$ to $1 \mathrm{nmol} / \mathrm{rat}$, maximum effect: $1 \mathrm{pmol} / \mathrm{rat}$ ) in conscious rats, suggesting a tonic inhibitory role of ghrelin in the central control of gastric secretion [38]. Conflicting results reported in urethaneanesthetized rats during intracerebroventricular application of ghrelin $(0.3,0.6$ or $1 \mathrm{nmol} / \mathrm{rat})$ [42] may be due to the effects of urethane on somatostatin release or, once again, to higher dosages used in the latter study. Taken together, peripheral application of low doses of ghrelin stimulated gastric secretion in most studies while higher doses had no or even inhibitory effects. In contrast, central application of ghrelin in conscious rats inhibited acid output at very low doses, higher doses had less impact or resulted in stimulation. An intact vagal system was essential for mediating central and peripheral effects [40, 42, 44]. The apparently discrepant impact of peripheral and central ghrelin at various doses may be explained by the existence of different receptor subtypes: two isoforms have been identified, the predominantly central GHS- $\mathrm{R}_{1 \mathrm{a}}$ receptor and the GHS- $\mathrm{R}_{1 b}$ receptor prevalent in the human fundus and antrum. The latter was thought to be inactive $[45,46]$ but has been attributed biological activity by recent authors $[47,48]$. Cell culture experiments suggest that a further, unidentified subtype, or even subtypes, of ghrelin receptor also exists [46].
The following hypothesis could explain the observations described above. Central ghrelin exerts a (tonic) inhibitory control of gastric acid secretion via GHS- $\mathrm{R}_{1 a}$ receptors at very low levels. Low levels of peripheral ghrelin release stimulate gastric acid secretion via GHS- $\mathrm{R}_{1 b}$ receptors or an as yet unidentified novel receptor subtype. As ghrelin is produced in the stomach, additional activation of central GHS- $\mathrm{R}_{1 a}$ receptors reverses the stimulatory effect. It has been observed that peripheral administration of ghrelin compared with intracerebroventricular application allows only limited access of the compound to hypothalamic sites. This may explain why high peripheral ghrelin concentrations are needed to induce inhibition [39]. Thus, under physiological conditions, the postprandial decrease in ghrelin plasma levels may release the inhibitory effect of central ghrelin and promote gastric acid secretion. It has to be emphasized that this scheme is based on the findings of animal studies as there have been no human studies on the effects of ghrelin on gastric acid secretion.

\section{Other Recently Discovered GI Peptide Hormones}

Amylin, a 37-aa peptide that shows 50\% homology with the calcitonin-gene-related peptide, is colocalized with somatostatin in endocrine cells of the gastric fundus [52] and released in response to meal ingestion. Endogenous amylin stimulates somatostatin secretion via an autocrine pathway, resulting in an inhibition of histamine and acid secretion [53]. Adrenomedullin, another member of the calcitonin family, is localized in ECL and chief cells in the oxyntic mucosa. Similar to amylin, it stimulates somatostatin secretion and thus inhibits histamine and acid secretion $[54,55]$. Different to amylin, the effect appears to be mediated via activation of intramural gastric fundic neurons since it is abolished by the axonal blocker tetrodotoxin [55]. The neuropeptide pituitary adenylate cyclase-activating peptide, which belongs to the glucagon/VIP family, stimulates both release of histamine from ECL cells and somatostatin release [56-58]. The resulting effect on gastric acid secretion is discussed inconsistently in the literature and depends on the species and experimental model used.

\section{Summary}

The control of gastric acid secretion depends on the central and peripheral effects of neuroendocrine hormones mediated directly and via vagal activity on the stomach. The initial cephalic and gastric response is predominantly stimulatory to gastric digestion, whereas the postgastric effects are inhibitory to maintain the correct 
intestinal $\mathrm{pH}$ for intestinal digestion. Numerous neurohormones have been attributed to play a part in the regulation of gastric acid secretion. Whereas gastrin, CCK and GLP-1 together with the more recently discovered GLP-2 are known to regulate gastric acid production, ghrelin and amylin yield dose- and application-dependent changes too inconsistent to clearly establish their role and human studies are largely unavailable.

\section{Gastric Acid and Digestive and Mucosal Processes}

\section{Calcium Absorption}

The dissociation of food calcium complexes and the liberation of $\mathrm{Ca}^{2+}$ from calcium salts is strongly dependent on $\mathrm{pH}$. This has led to the assumption that the presence of gastric acid is a necessary prerequisite for intestinal $\mathrm{Ca}^{2+}$ absorption. The negative effect of gastrectomy [59-61] or pernicious anemia [62] on bone mass supports this hypothesis. Moreover, a recent epidemiological study in patients older than 50 years revealed an increased risk of hip fracture in patients on long-term PPI [63]. Calcium is absorbed by two mechanisms: solubilization and conversion into its ionized form $\left(\mathrm{Ca}^{2+}\right)$ is efficient at low gastric $\mathrm{pH}$ and active absorption occurs in the duodenum and jejunum [64-67]. Passive calcium uptake occurs predominantly in the distal intestine and can compensate deficits in the active absorption pathway with high oral calcium uptake. Animal studies have yielded conflicting results regarding the influence of gastric acid on $\mathrm{Ca}^{2+} \mathrm{ab}-$ sorption, and some suggested normal overall $\mathrm{Ca}^{2+}$ intake at high oral intake even after complete suppression of gastric acid secretion $[68,69]$. However, recent trials in humans, including both normal subjects and high-risk populations (postmenopausal women, patients on dialysis) showed that the oral application of calcium results in a serum peak of ionized as well as protein-bound calcium, which is missing in the presence of a complete blockade of gastric acid [70-72]. Furthermore it has been shown that the total intestinal calcium resorption was significantly reduced in postmenopausal women during highdose PPI intake [73]. Gastrectomized rats rapidly lose bone mass [74-77], and in humans, gastrectomy also leads to osteopenia. The pathophysiology is multifactorial and may include hypergastrinemia, malabsorption, lack of oxyntic mucosa, vagal dysregulation with a disturbance of the gastrin-parathyreoid axis, and bacterial overgrowth. But also non-resective operations, like supraselective vagotomy, or disease, like pernicious anemia, result in osteopenia and an increased bone turnover.
In addition to reducing calcium absorption by inhibiting gastric acid, experimental studies have demonstrated that the inhibition of proton pump activity in osteoclasts has direct inhibitory effects on bone resorption and release of bone calcium [78, 79]. Although this effect may be discussed as a protective direct effect on bone tissue, it could further impair calcium metabolism and is another mechanism by which PPIs might contribute to the increased risk of hip fractures in elderly patients [63]. These patients require careful review as to their need for oral $\mathrm{Ca}^{+}$supplements and other forms of osteoporosis prophylaxis.

\section{Hematinic Absorption}

Dietary iron, present in food as either heme iron or non-heme iron, is absorbed predominantly in the duodenum. Acid is important for solubilization, reduction and subsequent absorption of dietary iron. Decreased absorption has been reported in patients with hypochlorhydric conditions, such as gastrectomy, vagotomy, multifocal atrophic gastritis and autoimmune gastritis. Therefore, clinical monitoring of anemia and iron levels in gastrectomized patients or during long-term acid secretion seem reasonable [80-87].

Hypochlorhydria affects also the absorption of vitamin $B_{12}$ (cobalamin) [88-92]. The vitamin is protein bound and is released in the presence of acid and pepsin. Vitamin $B_{12}$ is subsequently bound to haptocorrins and passes into the small intestine. There cobalamin is liberated by pancreatic proteases and bound to intrinsic factor, which protects the vitamin from catabolism by intestinal bacteria. Intrinsic factor also mediates the absorption in the terminal ileum. Reduced cobalamin assimilation has been observed in patients with chronic gastric hyposecretion, such as during chronic atrophic gastritis [93-96], long-term therapy with PPIs [90] and after vagotomy [92, 97]. Especially subsets of Helicobacter-pylori-infected persons have an increased risk to develop cobalamin deficiency. It remains unclear whether this is a direct effect of hypochlorhydria or indirect via small intestinal bacterial overgrowth. Nevertheless, periodic assessment of cobalamin levels has been recommended for patients on chronic anti-secretory therapy [90]. Patients with pernicious anemia have a normal life span on $B_{12}$ substitution therapy [98].

\section{Protein and Lipid Metabolism}

Acid secretion from gastric parietal cells facilitates protein and lipid digestion [99]. Pepsinogen, the most potent protease, is produced in gastric chief cells and is ac- 
tivated under acidic conditions below a pH level of 4. Under hypochlorhydric conditions, impaired digestion of proteins occur and malabsorption of proteins has been observed [100, 101], although muscular atrophy or weight loss are rare. In addition, small intestinal bacterial overgrowth in hypochlorhydria probably leads to reduced breakdown of the metobolically useful products of protein and lipid digestion, thereby reducing their availability for certain essential amino and fatty acids (e.g., tryptophan, tyrosine and arachidonic acid). This effect has been suggested as a precipitating factor for depression (tryptophan is a precursor of serotonin) and other health problems in hypochlorhydric patients [89].

\section{Differentiation and Regeneration of the Mucosal Epithelium}

The differentiation of the gastric epithelium depends on the presence of gastric acid. The human epithelium in the GI tract belongs to the most quickly regenerating tissues in the body. All types of stomach epithelial cells are derived from a single progenitor cell in each gland. These stem cells are able to divide and to proliferate continuously. In mice (HK-ATPase knock-outs) or rats artificially depleted of gastric acid (gastrectomy), the normal differentiation process is disturbed so that metaplastic cells arise and gastric function is altered [74-76]. The presence of acid affects the healing of ulcers and regeneration. Artificial ulcers generated in rats lead to the release of growth factors at the topical site of the mucosa. Several of the growth factors, such as the hepatocyte growth factor, are activated only in acidic milieu, and ulcer healing is paradoxically prolonged in the absence of acid in animal models [102].

The data concerning tissue differentiation and regeneration are contradictory. Gastric-acid-activated gene expression of CDx 2 in cellular models such as keratinocytes leads to metaplasia, similar to the development of specialized intestinal metaplasia in the distal esophagus, i.e., Barrett's esophagus [103-107]. However, absence of acid in mouse models may also lead to the differentiation of parietal cells into a pre-parietal and metaplastic state, not able to express HK-ATPase. Long-term acid suppression increases gastric metaplasia type II and atrophy, especially in the presence of $H$. pylori; however, these cells appear to represent a de-differentiated state and long-term follow-up studies have not demonstrated an increased risk of gastric cancer $[106,108]$. Nevertheless it is recommended that $H$. pylori is eradicated from patients requiring long-term acid suppression.

Do We Need Gastric Acid?

\section{Summary}

Gastric acid affects the solubilization, digestion and absorption of several key nutrients. The importance of acid secretion is not critical under physiological conditions in patients taking a normal western diet; however, pathologic conditions including chronic gastric inflammation, gastric atrophy and hypochlorhydria help reveal the contributory role of gastric acid. The need for calcium, iron and vitamin supplements should be monitored during long-term PPI treatment in high-risk patients, such as postmenopausal women. Long-term acid suppression can also lead to mucosal gastric metaplasia and atrophy. Although the risk of gastric carcinoma is not elevated, it seems reasonable to manage other risk factors (e.g., H. pylori) that may exacerbate these effects.

\section{Gastric Acid, GI Flora and Infection}

\section{GI Flora}

Ingestion of food and fluids via the oral route introduces bacteria and other microorganisms into the esophagus and upper GI tract. Disinfection of this material has been suggested as a major role for gastric acid, as both the stomach and the proximal small intestine are virtually free of bacterial pathogens [109]. If this role of gastric acid is so important, reduction or elimination of gastric acid should alter the flora of the stomach and small intestine.

\section{Stomach}

The acid environment of the stomach is a filter for bacteria from the oropharynx and from the swallowed food and drinks. Thus it is difficult to distinguish whether bacteria found in the stomach really colonize the stomach or whether these are transients. A recent genomic characterization of the gastric flora yielded 128 different strains of bacteria, 13 of which have not been characterized in vivo [110]. There is a relationship between gastric luminal $\mathrm{pH}$ and the number of organisms in diseases with reduced acid secretion [111-113] and during acid-suppression therapy [114-117]. This change seems to be dependent on the amount of gastric acid suppression as the increase in bacteria is greater with PPI than with $\mathrm{H}_{2}-\mathrm{RA}$ [118-120]. Patients on acid suppression due to gastroesophageal reflux disease (GERD) treated with either PPIs or $\mathrm{H}_{2}$-RAs have a similar prevalence of $H$. pylori but a higher prevalence of non- $H$. pylori bacteria than controls in gastric juice aspirations (61 and $60 \%$ vs. $29 \%$, respectively). They are mostly oropharangeal species and very rarely anaerobic [120]. In a systematic review [121], there was an increase of bacteria 
in gastric juice in 12 out of 13 studies, irrespective of the investigated drug, either $\mathrm{H}_{2}$-RAs (cimetidine, ranitidine) [122-132] or PPIs (omeprazole) [118, 133-139]. Growth at the mucosal surface may be detected in about $50 \%$ of patients after long-term treatment with any type of effective antisecretory drug $[119,140]$. There have been concerns that these bacteria may produce carcinogenic nitrosamines and increase the risk of gastric cancer, although there is no evidence that acid suppression increases nitrosamine production $[119,140]$. This could be explained by the fact that bacterially produced nitrosamines are at least partly dependent on acid catalyzation, a chemical process which occurs optimally at a $\mathrm{pH}$ of 2 . In contrast, acid suppression may decrease nitrosamine production, which could be most relevant at the gastro-esophageal border and cardia [141, 142].

The disease state of atrophic gastritis is associated with complete achlorhydria; however, also other secretory products (e.g., pepsinogen) are eliminated. In patients with atrophic gastritis there is a significant increase in total bacterial count of the gastric lumen, with predominantly coliform bacteria [143], but no data on the clinical consequence of these changes are currently available. Similarly an increase of coliform bacteria is observed after partial gastric resection and gastroenterostomy [143]. However, the postoperative changes of barrier function and motility changes are fundamental, so they cannot be attributed to changes in gastric acid secretion alone.

In summary, both the contamination of the gastric juice and the colonization of the gastric mucosa with non- $H$. pylori flora increased during long-term acid inhibition and they seem dependent on length and extent of acid elimination, the clinical significance of which remains to be determined [144].

Modulation of Acid Secretion by H. pylori and Risk of Intestinal Infection

H. pylori has been shown to modulate gastric acid secretion. However, the pattern in which modulation of acid secretion occurs varies from patient to patient. In Helicobacter-associated gastritis and $H$. pylori-associated duodenal ulcers increased acid secretion is found. It has been speculated that this is due to increased release of gastrin and diminished mucosal expression of somatostatin [145]. Bacterial products recognized via pattern recognition receptors and pro-inflammatory cytokines such as TNF $\alpha$ are likely to cause these changes. In gastritis involving the gastric corpus acid secretion is decreased [146]. The H. pylori-induced decrease of acid secretion has been reported to be moderate: a 24 -hour intragastric $\mathrm{pH}$ monitoring showed an increase in $\mathrm{pH}$ in patients without $H$. pylori infection from $1.4 \pm 0.1$ to $1.6 \pm 0.3$ in patients with $H$. pylori infection (median \pm SD; $\mathrm{p}<0.01$ ) [147]. H. pylori-associated mucosal atrophy may also contribute to reduced acid secretion; however this has not been correlated in detail.

Investigations whether $H$. pylori-associated decrease of gastric acid secretion increases the risk of typhoid fever did not show a causative role but a common risk of environmental exposure to both bacteria, e.g., poor hygiene [148]. In a similar study on the risk of cholera infection, the authors reported that the overall risk of cholera was not significantly increased among $H$. pylori-infected subjects; the risk of cholera of life-threatening severity, however, was significantly elevated [149]. It again is unclear whether suppression of acid secretion contributes to the risk of more severe cholera as the overall risk is not increased, which should be the case if an $H$. pylori-induced rise in gastric $\mathrm{pH}$ would predispose to more intestinal infections in general.

\section{Small Intestine}

There is evidence that continuous acid-suppression therapy can lead to bacterial overgrowth in the small intestine [150]. In a controlled prospective study, duodenal juice was obtained from patients on continuous 6-week PPI therapy and compared to controls. No patient in the control group had duodenal bacterial overgrowth, while in the omeprazole group bacterial overgrowth was found in $14(56 \%)$ patients, and the number of bacteria in the duodenal juice of patients treated with omeprazole was distinctly higher compared with the control group. Besides bacteria from the oral cavity, fecal-type bacteria were present in 7 of 14 and anaerobic bacteria in 3 of 14 patients; however, there was no apparent sign of clinical side effects or significant consequences of duodenal bacterial overgrowth [150]. In a subsequent prospective randomized study these effects were more marked in patients on omeprazole compared with patients on cimetidine. Moreover, gastric $\mathrm{pH}$ was higher in patients with bacterial overgrowth compared with those without; findings that support the contention that the incidence of gastric and duodenal overgrowth is dependent on the level of acid suppression.

\section{GI Infections}

Stomach

It is well known that some enteric pathogens are more acid-resistant than others. Escherichia coli and Shigella 
flexneri can both survive exposure to a $\mathrm{pH}$ of $2.0 \pm 2.5$, whereas Salmonella enterica typhimurium is killed following exposure to $\mathrm{pH} 3$. The ability to survive at a low $\mathrm{pH}$ is thought to be one factor that determines the infective dose required to cause disease [121]. From these observations it has been concluded that the presence of gastric acid has important implications for the survival of pathogens that have entered the GI tract. Suppression of gastric acid secretion may allow infection to occur following ingestion of a smaller number of inoculated pathogens such as Salmonella enterica or Listeria monocytogenes [131, 137, 151]. There is some evidence to support an increased risk of parasitic infections under conditions of reduced acid secretion [151-153]. Whether there is an increased risk of viral or bacterial gastroenteritis in patients receiving gastric-acid-suppression therapy remains controversial [154]. Neal and coworkers $[155,156]$ performed a case-control study that found omeprazole treatment in the month before infection to be associated with a 10 -fold increased risk of Campylobacter infection. Canani et al. [157] also investigated the frequency of gastroenteritis among children on gastric-acid-suppression therapy. They showed that subjects using acid-suppressing drugs were more likely to have acute gastroenteritis (OR 3.58; CI 1.87-6.86) than matched controls. No differences were observed between $\mathrm{H}_{2}$ blocker and PPI users in acute gastroenteritis.

\section{Small Intestine}

Gastric surgery is associated with increased rates of intestinal infections. The first report on salmonellosis following gastric surgery was of 9 cases of S. enterica $t$. infection published in the New England Journal of Medicine in 1956 [158]. A larger study comparing 277 patients with salmonella infection with 436 patients admitted to an infectious disease hospital suffering from other infections revealed a significantly higher number of cases of gastric surgery in the salmonella-infected group than in the control group. This was confirmed by a case-control study of laboratory-confirmed patients with a S. enterica infection with well-matched controls. Use of both $\mathrm{H}_{2}$ antagonists and PPIs were associated with a 4 -fold increased risk of endemic S. enterica enteritidis infection. PPIs were also linked to an 8-fold risk of endemic S. enterica $t$. infection; however, colonization with these bacteria had no clear clinical consequences [160]. A retrospective casecontrol study found an increased risk of Clostridium difficile diarrhea under current use of PPI therapy [161]. Similar results were obtained in a case-control study using a United Kingdom clinical research database. Expo- sure to a PPI in the 90 days before the index date of the study was associated with a 2- to 3 -fold increased risk of C. difficile-associated diarrhea [162-164].

With respect to Campylobacter jejuni infection, no association with acid suppression in a large prospective case-control study has been shown. Of the risk factors foreign travel, living on a farm, taking antibiotics or antacids, and having problems with rodents or houseflies in the home, only living on a farm was associated with illness (OR 2.484; 95\% CI 1.041-5.930) [165].

\section{Summary}

There has been growing attention to effects of acidsuppression therapy on gastric microbiology: gastric acid suppression leads to a quantitative increase and change of the gastric flora dependent on length and extent of acid suppression, which seems not to be translated into symptoms or changes in small intestinal absorptive function. However, there is growing evidence for an increased risk of bowel infection in states of chronic gastric acid suppression that may influence treatment decisions in certain situations.

\section{Gastric Acid and Hunger, Satiation and Mood}

\section{Central and Peripheral Control of Gastric Secretion}

The central nervous system has an important role in the regulation of gastric acid in primates. Sham feeding studies show that up to $50 \%$ of gastric acid secretion occurs during the cephalic phase of feeding [166]. This effect is mediated primarily by the vagus nerve directly or indirectly via release of various peptide hormones. The prosecretory influence of the central nervous system on gastric acid secretion is effectively blocked by sub-diaphragmatic vagotomy. Interestingly it was demonstrated that, in addition to well-known peptide hormones such as gastrin and somatostatin, recently discovered peptides such as ghrelin also modulate acid secretion [43]. The main source of gastrin and ghrelin is the gastric mucosa $[167,168]$; however, both are also produced by the hypothalamus $[34,169]$.

\section{Interaction between Control of Gastric Secretion and Feeding Behavior}

Gastrin tends to reduce feeding behavior in animal models [170], whereas ghrelin stimulates hunger and increases nutrient intake in various species [171], including humans [172]. Considered together these observations raise the question whether mechanisms that control gas- 
tric acid secretion have a direct influence on hunger, satiety and feeding behavior and thus on body weight. Moreover, given the close anatomical relationship of feeding centers and emotional centers in the hypothalamus and limbic system, it could be envisaged that modulating gastric acid secretion could have effects on emotional well-being. Information concerning these possibilities is very limited. Campbell et al. [170] investigated the effects of proton pump $\left(\mathrm{H}^{+} / \mathrm{K}^{+}\right.$-ATPase $)$inhibition by omeprazole on feeding behavior in hens. In addition to reduced gastric acid secretion, a reduction in energy intake was also observed. In these animal experiments, the reduction in feeding was attributed to the rise in gastrin levels with PPI inhibition by omeprazole [170]. Surprisingly, no similar experiments or observations have been reported in humans. What is established in humans is that underweight, malnourished patients have low levels of gastric acid secretion, whereas obese patients have a raised maximal secretory capacity (peak acid output) but normal basal acid output $[117,173,174]$. Studies in patients having had gastric banding surgery for morbid obesity have shown that peak acid output is significantly reduced following weight loss, whereas basal acid output is unchanged [175]. Together these observations suggest a link between body weight and acid secretion. Severe malnutrition is associated with parietal cell dysfunction, which may be the decisive control mechanism by which nutritional state influences gastric acid secretion. These findings provide interesting insights into the effect of feeding behavior, body weight, changes in body weight and gastric acid secretion. Nevertheless, despite the large number of clinical trials that involve PPIs, there is no clear link between gastric acid inhibition and feeding behavior or body weight. This could be due to the interaction between gastric acid production reflux symptoms and feeding behavior (e.g., reducing gastric acid production increases gastrin, which might inhibit food intake but reduces reflux symptoms that could well increase food intake).

\section{Gastric Secretion and Psychological State}

A related question is whether the presence or absence of gastric acid has a meaningful effect on mood or emotional state. Possible models that could help address this question include the study of conditions that are linked to reduced gastric acid secretion (atrophic gastritis, vagotomy, PPI therapy) and those in which gastric acid secretion is increased (Zollinger-Ellison syndrome, peptic diseases of the upper GI tract). Before the discovery of $H$. pylori, a number of attempts were made to establish a link between personality or emotional affect and peptic ulceration [176]. It was proposed that an elevated level of anxiety in patients with duodenal ulceration could lead to increased gastric acid production [177]. However, it was shown that although neuropsychological factors such as fear, stress and conflict did have effects on gastric acid production in healthy volunteers, the hypergastrinemia in peptic ulcer disease was independent of emotional state [178]. Moreover, it is possible that the characteristic 'ulcer personality' described in the literature is an effect rather than a cause of the disease [179]. New investigations in patients with GERD have revealed a further aspect of the relationship between stress, GI symptoms and disease: stress increases visceral sensitivity and the association between reflux events and symptoms [180]. On this basis it has been shown that symptoms associated with GERD can be reduced by relaxation training [181]. However, external stressors do not increase acute gastric acid secretion [182].

Very little data exist regarding the central perception of gastric acid and influence on affect or mood. Kern et al. [183] were able to show that, even below the conscious perception threshold, esophageal acid exposure leads to a rapid and intense cortical activation in GERD patients and healthy volunteers. This raises the question of how a potentially painful stimulus such as acid is perceived in gastrointestinal disease. Centrally active mediators that may play a role in this process include corticotropinereleasing hormone, $5-\mathrm{HT}_{3}$-receptor-ligands, melatonin und dopamine [184-187], all of which are thought to play a role not only in the response to pain and other stressful stimuli but also in psychological state. Epidemiological studies provide further evidence of the link between affective disorders and changes in gastric acid secretion and peptic ulcer disease: a Canadian study revealed that patients receiving antidepressant therapy had an increased usage of PPIs [188]. Moreover, a high percentage of patients with bipolar disorder have circulating anti-parietal antibodies [189]; however, it remains unclear whether these patients also have atrophic gastritis or hyposecretion of gastric acid.

\section{Summary}

There is little evidence for involvement of gastric acid or its suppression in sensation of hunger, satiation or mood. In animal models caloric intake was shown to be reduced under acid-suppression therapy; however, no clear link between acid suppression and changes in feeding behavior or body weight has been established. Gastric acid production may be acutely increased by neuropsy- 
chological factors such as anxiety or fear; however, in peptic ulcer disease it is independent of the emotional state. The characteristic 'ulcer personality' described in the literature may therefore be an effect rather than a cause of the disease. Future directions of studies will include not only the effects of gastric acid secretion on perception, mood and emotion, but also whether anti-secretory therapy has effects on central processes and how these are mediated. Early evidence that supports central effects of these medications suggest direct central anticonvulsive and anti-tussive effects for PPIs [190, 191].

\section{Conclusion}

Gastric acid plays a role in regulating gastric function, protects against GI pathogens, facilitates the digestion and absorption of certain nutrients and may modulate feeding behavior. These properties represent a clear advantage to individuals on the verge of starvation who need to extract every last nutrient from a limited, contaminated food supply in order to survive. This is the situation in which most humans existed until the very recent past and it continues to be the case in many individuals living in the developing world; however, it is only now becoming clear to what extent gastric acid has clini- cally relevant effects in the developed world. Although the absolute risk is low, acid suppression does increase the risk of GI infection and this may be of importance in community outbreaks, and especially in hospitals and nursing homes in the light of increasing virulence of bacterial strains such as $C$. difficile. Similarly, recent evidence suggests that the effect of acid suppression on calcium absorption increases the risk of hip fracture in atrisk populations. Long-term follow-up has not found evidence that potent acid suppression with PPIs is related to increasing rates of esophageal cancer or other malignant diseases; however, this needs to be monitored as patients embark on an essentially life-long therapy with these medications. Finally a better understanding of neuropsychological effects of gastric acid is required. The link between gastrointestinal 'humors', health and wellbeing has a history stretching back to Galen, and there surely is more to be understood about the way gastric acid affects GI function, feeding behavior and mood.

\section{Acknowledgments}

We thank T. Ganten, P. Kobelt, J. Kühn, M. Neubrand, C. Pehl, U. Peitz, R. Rad, S. Rath, D. Sauer, M. Schäfgen, P. Schiedermaier, A. Riphaus and V. Weingart, participants of the Kandahar Study Group, for discussion and literature retrieval.

\section{References}

$\checkmark 1$ Blum AL, Hegglin J, Krejs GJ, Largiader F, Sauberli H, Schmid P: Gastric emptying of organic acids in the dog. J Physiol 1976;261: 285-299.

-2 Holzer P, Painsipp E, Schuligoi R: Differential effects of intragastric acid and capsaicin on gastric emptying and afferent input to the rat spinal cord and brainstem. BMC Neurosci 2005;6:60.

$\checkmark 3$ Lin HC, Doty JE, Reedy TJ, Meyer JH: Inhibition of gastric emptying by acids depends on $\mathrm{pH}$, titratable acidity, and length of intestine exposed to acid. Am J Physiol 1990;259: G1025-G1030.

$\checkmark 4$ Raybould HE, Holzer HH: Duodenal acidinduced inhibition of gastric motility and emptying in rats. Am J Physiol 1993;265: G540-G546.

5 Lu YX, Owyang C: Duodenal acid-induced gastric relaxation is mediated by multiple pathways. Am J Physiol 1999;276:G1501G1506.

-6 Tucci A, Poli L, Biasco G, et al: Helicobacter pylori infection and gastric function in patients with fundic atrophic gastritis. Dig Dis Sci 2001;46:1573-1583.
Malagelada JR: Pathophysiological responses to meals in the Zollinger-Ellison syndrome. 2. Gastric emptying and its effect on duodenal function. Gut 1980;21:98-104.

$>8$ Hunt JN, Stubbs DF: The volume and energy content of meals as determinants of gastric emptying. J Physiol 1975;245:209-225.

$\checkmark 9$ Mangnall YF, Kerrigan DD, Johnson AG, Read NW: Applied potential tomography. Noninvasive method for measuring gastric emptying of a solid test meal. Dig Dis Sci 1991;36:1680-1684.

10 Woodtli W, Owyang C: Duodenal pH governs interdigestive motility in humans. Am J Physiol 1995;268:G146-G152.

11 Bortolotti M, Barbara L: Interdigestive gastroduodenal motor activity in subjects with increased gastric acid secretion. Digestion 1988;41:156-160.

12 Jones MP, Shah D, Ebert CC: Effects of rabeprazole sodium on gastric emptying, lectrogastrography, and fullness. Dig Dis Sci 2003;48:69-73

13 Camilleri M, Hasler WL, Parkman HP, Quigley EM, Soffer E: Measurement of gastrointestinal motility in the GI laboratory. Gastroenterology 1998;115:747-762.
14 Sorensen M, Tetzschner T, Rasmussen OO, Christiansen J: Relation between electromyography and anal manometry of the external anal sphincter. Gut 1991;32:1031-1034.

15 Tougas G, Earnest DL, Chen Y, Vanderkoy C, Rojavin M: Omeprazole delays gastric emptying in healthy volunteers: an effect prevented by tegaserod. Aliment Pharmacol Ther 2005;22:59-65.

16 Mays EE, Dubois JJ, Hamilton GB: Pulmonary fibrosis associated with tracheobronchial aspiration. A study of the frequency of hiatal hernia and gastroesophageal reflux in interstitial pulmonary fibrosis of obscure etiology. Chest 1976;69:512-515.

17 Benini L, Castellani G, Bardelli E, et al: Omeprazole causes delay in gastric emptying of digestible meals. Dig Dis Sci 1996;41: 469-474.

18 Forrest JA, Heading RC, Park J, et al: Effect of histamine $\mathrm{H}_{2}$-receptor blockade on gastric emptying and serum gastrin in man. Scott Med J 1976;21:23-27. 
19 Rasmussen L, Oster-Jorgensen E, Qvist N, Kraglund K, Hovendal C, Pedersen SA: Short report: a double-blind placebo-controlled trial of omeprazole on characteristics of gastric emptying in healthy subjects. Aliment Pharmacol Ther 1991;5:85-89.

-20 Horton JW, McClelland RN, Weger RV: Effect of parietal cell vagotomy on gastric emptying in duodenal ulcer disease. Am J Surg 1982;143:86-89.

-21 Mistiaen W, Van Hee R, Blockx P, Hubens A: Gastric emptying for solids in patients with duodenal ulcer before and after highly selective vagotomy. Dig Dis Sci 1990;35:310-316.

22 Yu P, Wang D, Cai Z, Wen Y: Long-term clinical results after highly selective vagotomy plus pylorus-preserved mucosal antrectomy. Chin J Surg 2002;40:650-652.

-23 Schmidt WE, Creutzfeldt W, Hocker M, et al: Cholecystokinin receptor antagonist loxiglumide modulates plasma levels of gastroentero-pancreatic hormones in man. Feedback control of cholecystokinin and gastrin secretion. Eur J Clin Invest 1991;21:501-511.

-24 Chung I, Li P, Lee K, Chang T, Chey WY: Dual inhibitory mechanism of secretin action on acid secretion in totally isolated, vascularly perfused rat stomach. Gastroenterology 1994;107:1751-1758.

-25 Shimizu K, Li P, Lee KY, Chang TM, Chey WY: The mechanism of inhibitory action of secretin on gastric acid secretion in conscious rats. J Physiol 1995;488:501-508.

26 Piqueras L, Tache Y, Martinez V: Galanin inhibits gastric acid secretion through a somatostatin-independent mechanism in mice. Peptides 2004;25:1287-1295.

-27 Drucker DJ: Biological actions and therapeutic potential of the glucagon-like peptides. Gastroenterology 2002;122:531-544.

-28 Yang H: Central and peripheral regulation of gastric acid secretion by peptide YY. Peptides 2002;23:349-358.

29 Hildebrand P, Lehmann FS, Ketterer S, et al: Regulation of gastric function by endogenous gastrin releasing peptide in humans: studies with a specific gastrin releasing peptide receptor antagonist. Gut 2001;49:2328.

-30 Wettergren A, Petersen H, Orskov C, Christiansen J, Sheikh SP, Holst JJ: Glucagon-like peptide-1 7-36 amide and peptide YY from the L-cell of the ileal mucosa are potent inhibitors of vagally induced gastric acid secretion in man. Scand J Gastroenterol 1994;29: 501-505.

-31 Wettergren A, Maina P, Boesby S, Holst JJ: Glucagon-like peptide-1 $7-36$ amide and peptide YY have additive inhibitory effect on gastric acid secretion in man. Scand J Gastroenterol 1997;32:552-555.

-32 Wojdemann M, Wettergren A, Hartmann B, Hilsted L, Holst JJ: Inhibition of sham feeding-stimulated human gastric acid secretion by glucagon-like peptide-2. J Clin Endocrinol Metab 1999;84:2513-2517.
33 Meier JJ, Nauck MA, Pott A, et al: Glucagonlike peptide 2 stimulates glucagon secretion, enhances lipid absorption, and inhibits gastric acid secretion in humans. Gastroenterology 2006;130:44-54.

34 Lu S, Guan JL, Wang QP, et al: Immunocytochemical observation of ghrelin-containing neurons in the rat arcuate nucleus. Neurosci Lett 2002;321:157-160.

- 35 Kojima M, Hosoda H, Date Y, Nakazato M, Matsuo H, Kangawa K: Ghrelin is a growthhormone-releasing acylated peptide from stomach. Nature 1999;402:656-660.

36 Peeters TL: Ghrelin: a new player in the control of gastrointestinal functions. Gut 2005; 54:1638-1649.

37 Dornonville de la Cour C, Lindstrom E, Norlen P, Hakanson R: Ghrelin stimulates gastric emptying but is without effect on acid secretion and gastric endocrine cells. Regul Pept 2004;120:23-32.

38 Sibilia V, Pagani F, Guidobono F, et al: Evidence for a central inhibitory role of growth hormone secretagogues and ghrelin on gastric acid secretion in conscious rats. Neuroendocrinology 2002;75:92-97.

39 Sibilia V, Muccioli G, Deghenghi R, et al: Evidence for a role of the GHS- $\mathrm{R}_{1 \mathrm{a}}$ receptors in ghrelin inhibition of gastric acid secretion in the rat. J Neuroendocrinol 2006;18:122128.

40 Masuda Y, Tanaka T, Inomata N, et al: Ghrelin stimulates gastric acid secretion and motility in rats. Biochem Biophys Res Commun 2000;276:905-908.

41 Levin F, Edholm T, Ehrstrom M, et al: Effect of peripherally administered ghrelin on gastric emptying and acid secretion in the rat. Regul Pept 2005;131:59-65.

42 Date Y, Nakazato M, Murakami N, Kojima M, Kangawa K, Matsukura S: Ghrelin acts in the central nervous system to stimulate gastric acid secretion. Biochem Biophys Res Commun 2001;280:904-907.

43 Brzozowski T, Konturek PC, Konturek SJ, et al: Exogenous and endogenous ghrelin in gastroprotection against stress-induced gastric damage. Regul Pept 2004;120:39-51.

44 Brzozowski T, Konturek PC, Sliwowski Z, et al: Prostaglandin/cyclooxygenase pathway in ghrelin-induced gastroprotection against ischemia-reperfusion injury. J Pharmacol Exp Ther 2006;319:477-487.

45 Gnanapavan S, Kola B, Bustin SA, et al: The tissue distribution of the mRNA of ghrelin and subtypes of its receptor, GHS-R, in humans. J Clin Endocrinol Metab 2002;87: 2988.

46 Kojima M, Kangawa K: Ghrelin: structure and function. Physiol Rev 2005;85:495-522.

47 Barzon L, Pacenti M, Masi G, Stefani AL, Fincati K, Palu G: Loss of growth hormone secretagogue receptor la and overexpression of type $1 \mathrm{~b}$ receptor transcripts in human adrenocortical tumors. Oncology 2005;68: $414-421$.
$48 \mathrm{Xu}$ L, Depoortere I, Tomasetto C, et al: Evidence for the presence of motilin, ghrelin, and the motilin and ghrelin receptor in neurons of the myenteric plexus. Regul Pept 2005; 124:119-125.

49 Moechars D, Depoortere I, Moreaux B, et al: Altered gastrointestinal and metabolic function in the GPR39-obestatin receptor-knockout mouse. Gastroenterology 2006;131: 1131-1141.

50 Lauwers E, Landuyt B, Arckens L, Schoofs L, Luyten W: Obestatin does not activate orphan G protein-coupled receptor GPR39. Biochem Biophys Res Commun 2006;351:21-25.

51 Tremblay F, Perreault M, Klaman LD, Tobin JF, Smith E, Gimeno RE: Normal food intake and body weight in mice lacking the G protein-coupled receptor GPR39. Endocrinology 2007;148:501-506

52 Mulder H, Lindh AC, Ekblad E, Westermark $\mathrm{P}$, Sundler F: Islet amyloid polypeptide is expressed in endocrine cells of the gastric mucosa in the rat and mouse. Gastroenterology 1994;107:712-719.

53 Zaki M, Koduru S, McCuen R, Vuyyuru L, Schubert ML: Amylin, released from the gastric fundus, stimulates somatostatin and thus inhibits histamine and acid secretion in mice. Gastroenterology 2002;123:247-255.

54 Rossowski WJ, Cheng BL, Jiang NY, Coy $\mathrm{DH}$ : Examination of somatostatin involvement in the inhibitory action of GIP, GLP-1, amylin and adrenomedullin on gastric acid release using a new SRIF antagonist analogue. Br J Pharmacol 1998;125:1081-1087.

55 Hirsch AB, McCuen RW, Arimura A, Schubert ML: Adrenomedullin stimulates somatostatin and thus inhibits histamine and acid secretion in the fundus of the stomach. Regul Pept 2003;110:189-195.

56 Li P, Chang TM, Coy D, Chey WY: Inhibition of gastric acid secretion in rat stomach by PACAP is mediated by secretin, somatostatin, and PGE(2). Am J Physiol 2000;278: G121-G127.

57 Sandvik AK, Cui G, Bakke I, Munkvold B, Waldum HL: PACAP stimulates gastric acid secretion in the rat by inducing histamine release. Am J Physiol 2001;281:G997-G1003.

58 Tornoe K, Hannibal J, Georg B, et al: PACAP 1-38 as neurotransmitter in the porcine antrum. Regul Pept 2001;101:109-121.

59 Pyrah LN, Smith IB: Osteomalacia following gastrectomy. Lancet 1956;270:935-937.

60 Mitchell AB, Glass D, Gill AM: Bone disease after gastrectomy. Br Med J 1972;2:164.

61 Heiskanen JT, Kroger H, Paakkonen M, Parviainen MT, Lamberg-Allardt C, Alhava E: Bone mineral metabolism after total gastrectomy. Bone 2001;28:123-127.

62 Eastell R, Vieira NE, Yergey AL, et al: Pernicious anaemia as a risk factor for osteoporosis. Clin Sci (Lond) 1992;82:681-685.

63 Yang YX, Lewis JD, Epstein S, Metz DC: Long-term proton pump inhibitor therapy and risk of hip fracture. JAMA 2006;296: 2947-2953. 
64 Champagne ET: Low gastric hydrochloric acid secretion and mineral bioavailability. Adv Exp Med Biol 1989;249:173-184.

65 Bronner F, Stein WD: Calcium homeostasis - an old problem revisited. J Nutr 1995; 125:1987S-1995S.

66 Bronner F: Mechanisms and functional aspects of intestinal calcium absorption. J Exp Zoolog A Comp Exp Biol 2003;300:47-52.

67 Bronner F: Mechanisms of intestinal calcium absorption. J Cell Biochem 2003;88:387393.

-68 Bo-Linn GW, Davis GR, Buddrus DJ, Morawski SG, Santa Ana C, Fordtran JS: An evaluation of the importance of gastric acid secretion in the absorption of dietary calcium. J Clin Invest 1984;73:640-647.

69 Guinotte F, Gautron J, Nys Y, Soumarmon A: Calcium solubilization and retention in the gastrointestinal tract in chicks (Gallus domesticus) as a function of gastric acid secretion inhibition and of calcium carbonate particle size. Br J Nutr 1995;73:125-139.

70 Graziani G, Badalamenti S, Como G, et al: Calcium and phosphate plasma levels in dialysis patients after dietary Ca-P overload. Role of gastric acid secretion. Nephron 2002; 91:474-479.

71 Graziani G, Como G, Badalamenti S, et al: Effect of gastric acid secretion on intestinal phosphate and calcium absorption in normal subjects. Nephrol Dial Transplant 1995; 10:1376-1380.

72 Marcelli D, Locatelli F, Alberti D, et al: Hypertension as a factor in chronic renal insufficiency progression in polycystic kidney disease. The Northern Italian Cooperative Study Group. Nephrol Dial Transplant 1995; 10(suppl 6):15-17.

73 O'Connell MB, Madden DM, Murray AM, Heaney RP, Kerzner LJ: Effects of proton pump inhibitors on calcium carbonate absorption in women: a randomized crossover trial. Am J Med 2005; 118:778-781.

-74 Maier GW, Kreis ME, Zittel TT, Becker HD: Calcium regulation and bone mass loss after total gastrectomy in pigs. Ann Surg 1997; 225:181-192.

75 Glatzle J, Piert M, Meile T, et al: Prevalence of vertebral alterations and the effects of calcium and vitamin D supplementation on calcium metabolism and bone mineral density after gastrectomy. Br J Surg 2005;92:579585.

76 Zittel TT, Zeeb B, Maier GW, et al: High prevalence of bone disorders after gastrectomy. Am J Surg 1997;174:431-438.

-77 Persson P, Gagnemo-Persson R, Chen D, et al: Gastrectomy causes bone loss in the rat: is lack of gastric acid responsible? Scand J Gastroenterol 1993;28:301-306.

-78 Mizunashi K, Furukawa Y, Katano K, Abe K: Effect of omeprazole, an inhibitor of $\mathrm{H}^{+}, \mathrm{K}^{+}$ATPase, on bone resorption in humans. Calcif Tissue Int 1993;53:21-25.

Do We Need Gastric Acid?
9 Tuukkanen J, Väänänen HK: Omeprazole, a specific inhibitor of $\mathrm{H}^{+}-\mathrm{K}^{+}$-ATPase, inhibits bone resorption in vitro. Calcif Tissue Int 1986;38:123-125.

80 Bezwoda W, Charlton R, Bothwell T, Torrance J, Mayet F: The importance of gastric hydrochloric acid in the absorption of nonheme food iron. J Lab Clin Med 1978;92:108116.

81 Conrad ME, Schade SG: Ascorbic acid chelates in iron absorption: a role for hydrochloric acid and bile. Gastroenterology 1968;55: 35-45.

82 Cook JD, Brown GM, Valberg LS: The effect of achylia gastrica on iron absorption. J Clin Invest 1964;43:1185-1191.

83 Goldberg A, Lochhead AC, Dagg JH: Histamine-fast achlorhydria and iron absorption. Lancet 1963;1:848-850.

84 Schade SG, Cohen RJ, Conrad ME: Effect of hydrochloric acid on iron absorption. N Engl J Med 1968;279:672-674.

85 Lochhead AC, Goldberg A: Mechanisms in the transfer of protein-bound iron for haem biosynthesis. Clin Sci 1963;24:229-237.

86 Wheldon EJ, Venables CW, Johnston ID: The relationship of gastric secretion to anemia over 15 years following vagotomy and gastroenterostomy. Gut 1970;11:1056.

87 Wheldon EJ, Venables CW, Johnston ID: Late metabolic sequelae of vagotomy and gastroenterostomy. Lancet 1970;1:437-440.

88 Carmel R, Perez-Perez GI, Blaser MJ: Helicobacter pylori infection and food-cobalamin malabsorption. Dig Dis Sci 1994;39:309314.

89 Cater RE 2nd: The clinical importance of hypochlorhydria (a consequence of chronic $\mathrm{He}$ licobacter infection): its possible etiological role in mineral and amino acid malabsorption, depression, and other syndromes. Med Hypotheses 1992;39:375-383.

90 Jensen RT: Consequences of long-term proton pump blockade: insights from studies of patients with gastrinomas. Basic Clin Pharmacol Toxicol 2006;98:4-19.

91 King CE, Leibach J, Toskes PP: Clinically significant vitamin $\mathrm{B}_{12}$ deficiency secondary to malabsorption of protein-bound vitamin $\mathrm{B}_{12}$. Dig Dis Sci 1979;24:397-402.

92 Streeter AM, Duraiappah B, Boyle R, O’Neill BJ, Pheils MT: Malabsorption of vitamin $\mathrm{B}_{12}$ after vagotomy. Am J Surg 1974;128:340343.

93 Doscherholmen A, Swaim WR: Impaired assimilation of egg Co 57 vitamin $B_{12}$ in patients with hypochlorhydria and achlorhydria and after gastric resection. Gastroenterology 1973;64:913-919.

94 Doscherholmen A, Ripley D, Chang S, Silvis SE: Influence of age and stomach function on serum vitamin $\mathrm{B}_{12}$ concentration. Scand J Gastroenterol 1977;12:313-319.

95 Mahmud K, Ripley D, Swaim WR, Doscherholmen A: Hematologic complications of partial gastrectomy. Ann Surg 1973;177: 432-435. $\checkmark 96$ Salom IL, Silvis SE, Doscherholmen A: Effect of cimetidine on the absorption of vitamin $\mathrm{B}_{12}$. Scand J Gastroenterol 1982;17: 129-131.

$\$ 97$ Paimela H, Ahonen J, Hockerstedt K, Scheinin TM: Serum vitamin $B_{12}$ concentration after proximal gastric vagotomy. Scand J Gastroenterol 1984;19:445-448.

$\checkmark 98$ Whittingham S, Mackay IR: Autoimmune gastritis: historical antecedents, outstanding discoveries, and unresolved problems. Int Rev Immunol 2005;24:1-29.

99 Schubert ML: Gastric secretion. Curr Opin Gastroenterol 2003;19:519-525.

100 Jeffries GH, Weser E, Sleisenger MH: Malabsorption. Gastroenterology 1964;46: 434-466.

101 Toffolon EP, Goldfinger SE: Malabsorption following gastrectomy and ileal resection. Surg Clin North Am 1974;54:647-653.

102 Kinoshita Y, Hassan MS, Kawamura M, et al: Increased hepatocyte growth factor content in rat stomach during omeprazole treatment. Digestion 1998;59:102-109.

103 Brabletz T, Spaderna S, Kolb J, et al: Downregulation of the homeodomain factor CDx2 in colorectal cancer by collagen type I: an active role for the tumor environment in malignant tumor progression. Cancer Res 2004;64:6973-6977.

104 Faller G, Dimmler A, Rau T, et al: Evidence for acid-induced loss of CDx2 expression in duodenal gastric metaplasia. J Pathol 2004; 203:904-908.

105 Faller G, Kirchner T: Immunological and morphogenic basis of gastric mucosa atrophy and metaplasia. Virchows Arch 2005; 446:1-9.

106 Creutzfeldt WC, Blum AL: Safety of omeprazole. Lancet 1994;343:1098.

107 Marchetti M, Caliot E, Pringault E: Chronic acid exposure leads to activation of the $\mathrm{CDx} 2$ intestinal homeobox gene in a longterm culture of mouse esophageal keratinocytes. J Cell Sci 2003;116:1429-1436.

108 Lamberts R, Creutzfeldt W, Struber HG, Brunner G, Solcia E: Long-term omeprazole therapy in peptic ulcer disease: gastrin, endocrine cell growth, and gastritis. Gastroenterology 1993;104:1356-1370.

109 Howden CW, Hunt RH: Relationship between gastric secretion and infection. Gut 1987;28:96-107.

110 Bik EM, Eckburg PB, Gill SR, et al: Molecular analysis of the bacterial microbiota in the human stomach. Proc Natl Acad Sci USA 2006; 103:732-737.

111 Drasar BS, Hughes WH, Williams RE, Shiner M: Bacterial flora of the normal intestine. Proc R Soc Med 1966;59:1243.

112 Drasar BS, Shiner M, McLeod GM: Studies on the intestinal flora. 1 . The bacterial flora of the gastrointestinal tract in healthy and achlorhydric persons. Gastroenterology 1969;56:71-79. 
113 Franklin MA, Skoryna SC: Studies on natural gastric flora. 1. Bacterial flora of fasting human subjects. Can Med Assoc J 1966;95: 1349-1355.

114 Stockbruegger RW, Cotton PB, Menon GG, et al: Pernicious anaemia, intragastric bacterial overgrowth, and possible consequences. Scand J Gastroenterol 1984;19: 355-364.

115 Brummer RJ, Stockbrugger RW: Effect of nizatidine $300 \mathrm{mg}$ at night and omeprazole $20 \mathrm{mg}$ in the morning on 24-hour intragastric $\mathrm{pH}$ and bacterial overgrowth in patients with acute duodenal ulcer. Dig Dis Sci 1996;41:2048-2054.

116 Thomas JM, Misiewicz JJ, Cook AR, et al: Effects of one year's treatment with ranitidine and of truncal vagotomy on gastric contents. Gut 1987;28:726-738.

$\checkmark 117$ Winter TA, Marks T, Callanan M, O’Keefe SJ, Bridger S: Impaired pancreatic secretion in severely malnourished patients is a consequence of primary pancreatic dysfunction. Nutrition 2001;17:230-235.

118 Thorens J, Froehlich F, Schwizer W, et al: Bacterial overgrowth during treatment with omeprazole compared with cimetidine: a prospective randomised double blind study. Gut 1996;39:54-59.

-119 Sanduleanu S, Jonkers D, De Bruine A, Hameeteman W, Stockbrugger RW: Non-Helicobacter pylori bacterial flora during acidsuppressive therapy: differential findings in gastric juice and gastric mucosa. Aliment Pharmacol Ther 2001;15:379-388.

120 Sanduleanu S, Jonkers D, De Bruine A, Hameeteman W, Stockbrugger RW: Double gastric infection with Helicobacter pylori and non-Helicobacter pylori bacteria during acid-suppressive therapy: increase of pro-inflammatory cytokines and development of atrophic gastritis. Aliment Pharmacol Ther 2001;15:1163-1175.

121 Williams C: Occurrence and significance of gastric colonization during acid-inhibitory therapy. Best Pract Res Clin Gastroenterol 2001;15:511-521.

122 Bourne JT, Mountford RA, Barry RE: Twice-daily cimetidine does not increase gastric bacterial flora. Postgrad Med J 1984; 60:464-466.

123 Ruddell WS, Axon AT, Findlay JM, Bartholomew BA, Hill MJ: Effect of cimetidine on the gastric bacterial flora. Lancet 1980;1:672-674.

$\checkmark 124$ Reed PI, Smith PL, Haines K, House FR, Walters CL: Effect of cimetidine on gastric juice $\mathrm{N}$-nitrosamine concentration. Lancet 1981;2:553-556

125 Stockbrugger RW, Cotton PB, Eugenides N, Bartholomew BA, Hill MJ, Walters CL: Intragastric nitrites, nitrosamines, and bacterial overgrowth during cimetidine treatment. Gut 1982;23:1048-1054.
126 Snepar R, Poporad GA, Romano JM, Kobasa WD, Kaye D: Effect of cimetidine and antacid on gastric microbial flora. Infect Immun 1982;36:518-524.

127 Milton-Thompson GJ, Lightfoot NF, Ahmet $\mathrm{Z}$, et al: Intragastric acidity, bacteria, nitrite, and N-nitroso compounds before, during, and after cimetidine treatment. Lancet 1982;1:1091-1095.

128 Garcia del Risco F, Rolin O, Farinotti R, et al: Influence of ranitidine during a 24-hour period on the level of nitrites, nitrates, nitrosamines and bacterial flora in the gastric juice of healthy subjects (in French). Gastroenterol Clin Biol 1984;8:749-753.

129 Amin N: Giardiasis: a common cause of diarrheal disease. Postgrad Med 1979;66:151156, 158.

130 Gray JD, Shiner M: Influence of gastric $\mathrm{pH}$ on gastric and jejunal flora. Gut 1967;8:7481.

131 Giannella RA, Broitman SA, Zamcheck N: Gastric acid barrier to ingested microorganisms in man: studies in vivo and in vitro. Gut 1972;13:251-256.

132 Dellipiani AW, Girdwood RH: Bacterial changes in the small intestine in malabsorptive states and in pernicious anaemia. Clin Sci 1964;26:359-374.

133 Mowat C, Williams C, Gillen D, et al: Omeprazole, Helicobacter pylori status, and alterations in the intragastric milieu facilitating bacterial N-nitrosation. Gastroenterology 2000;119:339-347.

134 Sharma BK, Santana IA, Wood EC, et al: Intragastric bacterial activity and nitrosation before, during, and after treatment with omeprazole. Br Med J (Clin Res Ed) 1984;289:717-719.

135 Verdu E, Viani F, Armstrong D, et al: Effect of omeprazole on intragastric bacterial counts, nitrates, nitrites, and $\mathrm{N}$-nitroso compounds. Gut 1994;35:455-460.

136 Viani F, Siegrist HH, Pignatelli B, et al: The effect of intra-gastric acidity and flora on the concentration of $\mathrm{N}$-nitroso compounds in the stomach. Eur J Gastroenterol Hepatol 2000;12:165-173.

137 Glupczynski Y: Prolonged gastric acid suppression therapy: a significant risk factor for Listeria monocytogenes infection? Eur J Gastroenterol Hepatol 1996;8:1063-1066.

138 Toeg A, Berger SA, Battat A, Hoffman M, Yust I: Vibrio cholerae bacteremia associated with gastrectomy. J Clin Microbiol 1990;28:603-604.

139 Theisen J, Nehra D, Citron D, et al: Suppression of gastric acid secretion in patients with gastroesophageal reflux disease results in gastric bacterial overgrowth and deconjugation of bile acids. J Gastrointest Surg 2000;4:50-54.

140 Williams C, McColl KE: Review article: proton pump inhibitors and bacterial overgrowth. Aliment Pharmacol Ther 2006;23: 3-10.
141 Winter JW, Paterson S, Scobie G, Wirz A, Preston T, McColl KE: N-nitrosamine generation from ingested nitrate via nitric oxide in subjects with and without gastroesophageal reflux. Gastroenterology 2007; 133:164-174.

142 Moriya A, Grant J, Mowat C, et al: In vitro studies indicate that acid catalysed generation of $\mathrm{N}$-nitrosocompounds from dietary nitrate will be maximal at the gastro-oesophageal junction and cardia. Scand J Gastroenterol 2002;37:253-261.

143 Yeomans ND, Brimblecombe RW, Elder J, et al: Effects of acid suppression on microbial flora of upper gut. Dig Dis Sci 1995; 40(2 suppl):81S-95S.

144 Larner AJ, Hamilton MI: Review article: infective complications of therapeutic gastric acid inhibition. Aliment Pharmacol Ther 1994;8:579-584.

145 Kaneko H, Konagaya T, Kusugami K: Helicobacter pylori and gut hormones. J Gastroenterol 2002;37:77-86.

146 Shimatani T, Inoue M, Iwamoto K, et al: Gastric acidity in patients with follicular gastritis is significantly reduced, but can be normalized after eradication for Helicobacter pylori. Helicobacter 2005; 10:256265.

147 Tsai SH, Chen CM, Chang CS, Chen GH: Effect of Helicobacter pylori infection on intragastric acidity in patients with reflux esophagitis. J Gastroenterol 2004;39:821826.

148 Vollaard AM, Verspaget HW, Ali S, et al: Helicobacter pylori infection and typhoid fever in Jakarta, Indonesia. Epidemiol Infect 2006;134:163-170.

149 Clemens J, Albert MJ, Rao M, et al: Impact of infection by Helicobacter pylori on the risk and severity of endemic cholera. J Infect Dis 1995; 171:1653-1656.

150 Fried M, Siegrist H, Frei R, et al: Duodenal bacterial overgrowth during treatment in outpatients with omeprazole. Gut 1994;35: 23-26.

151 Cook GC: Infective gastroenteritis and its relationship to reduced gastric acidity. Scand J Gastroenterol Suppl 1985;111:1723.

152 Giannella RA, Broitman SA, Zamcheck N: Influence of gastric acidity on bacterial and parasitic enteric infections. A perspective. Ann Intern Med 1973;78:271-276.

153 Martinsen TC, Bergh K, Waldum HL: Gastric juice: a barrier against infectious diseases. Basic Clin Pharmacol Toxicol 2005; 96:94-102.

154 Laine L, Ahnen D, McClain C, Solcia E, Walsh JH: Review article: potential gastrointestinal effects of long-term acid suppression with proton pump inhibitors. Aliment Pharmacol Ther 2000;14:651-668.

155 Neal KR, Scott HM, Slack RC, Logan RF: Omeprazole as a risk factor for campylobacter gastroenteritis: case-control study. BMJ 1996;312:414-415. 
156 Neal K, Logan R: Potential gastrointestinal effects of long-term acid suppression with proton pump inhibitors. Aliment Pharmacol Ther 2001;15:1085-1086.

157 Canani RB, Cirillo P, Roggero P, et al: Therapy with gastric acidity inhibitors increases the risk of acute gastroenteritis and community-acquired pneumonia in children. Pediatrics 2006;117:e817-e820.

158 Kunz LJ, Waddell WR: Association of Salmonella enteritis with operations on the stomach. N Engl J Med 1956;255:555-559.

159 Giannella RA, Broitman SA, Zamcheck N: Salmonella enteritis. 1. Role of reduced gastric secretion in pathogenesis. Am J Dig Dis 1971;16:1000-1006.

160 Doorduyn Y, Van Den Brandhof WE, Van Duynhoven YT, Wannet WJ, Van Pelt W: Risk factors for Salmonella enteritidis and Typhimurium (DT104 and non-DT104) infections in The Netherlands: predominant roles for raw eggs in enteritidis and sandboxes in Typhimurium infections. Epidemiol Infect 2006;134:617-626.

161 Cunningham R, Dale B, Undy B, Gaunt N Proton pump inhibitors as a risk factor for Clostridium difficile diarrhoea. J Hosp Infect 2003;54:243-245.

162 Dial S, Alrasadi K, Manoukian C, Huang A, Menzies D: Risk of Clostridium difficile diarrhea among hospital inpatients prescribed proton pump inhibitors: cohort and case-control studies. CMAJ 2004;171:3338.

163 Dial S, Delaney JA, Barkun AN, Suissa S: Use of gastric acid-suppressive agents and the risk of community-acquired Clostridi um difficile-associated disease. JAMA 2005;294:2989-2995.

164 Dial S, Delaney JA, Schneider V, Suissa S Proton pump inhibitor use and risk of community-acquired Clostridium difficile-associated disease defined by prescription for oral vancomycin therapy. CMAJ 2006;175: 745-748.

165 Potter RC, Kaneene JB, Hall WN: Risk factors for sporadic Campylobacter jejuni infections in rural Michigan: a prospective case-control study. Am J Public Health 2003;93:2118-2123.

166 Konturek SJ, Bielanski W, Solomon TE: Effects of an antral mucosectomy, L-364,718 and atropine on cephalic phase of gastric and pancreatic secretion in dogs. Gastroenterology 1990;98:47-55.

167 Ariyasu H, Takaya K, Tagami T, et al: Stomach is a major source of circulating ghrelin, and feeding state determines plasma ghrelin-like immunoreactivity levels in humans. J Clin Endocrinol Metab 2001;86: 4753-4758.
168 Date Y, Kojima M, Hosoda H, et al: Ghrelin, a novel growth hormone-releasing acylated peptide, is synthesized in a distinct endocrine cell type in the gastrointestinal tracts of rats and humans. Endocrinology 2000; 141:4255-4261.

169 Cowley MA, Smith RG, Diano S, et al: The distribution and mechanism of action of ghrelin in the CNS demonstrates a novel hypothalamic circuit regulating energy homeostasis. Neuron 2003;37:649-661.

170 Campbell BJ, Dimaline R, Dockray GJ, Hughes J: Inhibition of food intake by omeprazole in the chicken. Eur J Pharmacol 1991;209:231-235.

171 Nakazato M, Murakami N, Date Y, et al: A role for ghrelin in the central regulation of feeding. Nature 2001;409:194-198.

172 Wren AM, Seal LJ, Cohen MA, et al: Ghrelin enhances appetite and increases food intake in humans. J Clin Endocrinol Metab 2001;86:5992.

173 Winter TA, O’Keefe S J, Callanan M, Marks $\mathrm{T}$ : Impaired gastric acid and pancreatic enzyme secretion in patients with Crohn's disease may be a consequence of a poor nutritional state. Inflamm Bowel Dis 2004;10: 618-625.

174 Wisen O, Rossner S, Johansson C: Gastric secretion in massive obesity. Evidence for abnormal response to vagal stimulation. Dig Dis Sci 1987;32:968-972.

175 Granstrom L, Backman L: Gastric acid secretion in extremely obese subjects before and after gastric banding. Acta Chir Scand 1987; 153:105-108.

176 Magni G, Rizzardo R, Di Mario F, Farini R, Aggio L, Naccarato R: Personality and psychological factors in chronic duodenal ulcer. Their interaction with biological parameters. Schweiz Arch Neurol Neurochir Psychiatr 1984;135:315-320.

177 Bresnick WH, Rask-Madsen C, Hogan DL, Koss MA, Isenberg JI: The effect of acute emotional stress on gastric acid secretion in normal subjects and duodenal ulcer patients. J Clin Gastroenterol 1993;17:117122.

178 Feldman M, Walker P, Goldschmiedt M, Cannon D: Role of affect and personality in gastric acid secretion and serum gastrin concentration. Comparative studies in normal men and in male duodenal ulcer patients. Gastroenterology 1992;102:175180.

179 Jess P: Gastric acid secretion in relation to personality, affect and coping ability in duodenal ulcer patients. A multivariate analysis. Hvidovre Ulcer Project Group. Dan Med Bull 1994;41:100-103.
180 Wright CE, Ebrecht M, Mitchell R, Anggiansah A, Weinman J: The effect of psychological stress on symptom severity and perception in patients with gastro-oesophageal reflux. J Psychosom Res 2005;59:415424.

181 McDonald-Haile J, Bradley LA, Bailey MA, Schan CA, Richter JE: Relaxation training reduces symptom reports and acid exposure in patients with gastroesophageal reflux disease. Gastroenterology 1994;107: 61-69.

182 Holtmann G, Singer MV, Kriebel R, Stacker $\mathrm{KH}$, Goebell H: Differential effects of acute mental stress on interdigestive secretion of gastric acid, pancreatic enzymes, and gastroduodenal motility. Dig Dis Sci 1989;34: 1701-1707.

183 Kern M, Hofmann C, Hyde J, Shaker R: Characterization of the cerebral cortical representation of heartburn in GERD patients. Am J Physiol Gastrointest Liver Physiol 2004;286:G174-G181.

184 Glavin GB, Hall AM: Central nervous system and gut interactions: dopamine and experimental gastroduodenal lesions. J Gastroenterol Hepatol 1994;9(suppl 1): S36-S39.

185 Kern W, Schiefer B, Schwarzenburg J, Stange EF, Born J, Fehm HL: Evidence for central nervous effects of corticotropin-releasing hormone on gastric acid secretion in humans. Neuroendocrinology 1997;65: 291-298.

186 Kato K, Murai I, Asai S, et al: Central nervous system action of melatonin on gastric acid and pepsin secretion in pylorus-ligated rats. Neuroreport 1998;9:3989-3992.

187 Nomura K, Maeda N, Yoshino T, Yamaguchi I: A mechanism of $5-\mathrm{HT}_{3}$ receptor mediation is involved etiologically in the psychological stress lesion the stomach of the mouse. J Pharmacol Exp Ther 1994;271: 100-106.

188 Ma J, Vaillancourt R, Boddam R, Auger S, Sampalis J: Association between antidepressant use and prescribing of gastric acid suppressants. Can J Psychiatry 2006;51: 178-184.

189 Padmos RC, Bekris L, Knijff EM, et al: A high prevalence of organ-specific autoimmunity in patients with bipolar disorder. Biol Psychiatry 2004;56:476-482.

190 Fireman Z, Kopelman Y, Sternberg A: Central nervous system side effects after proton pump inhibitor treatment. J Clin Gastroenterol 1997;25:718.

191 Chung KF: $\mathrm{H}^{+} / \mathrm{K}^{+}$-ATPase (proton pump) inhibitors dampen increased cough reflex: more than gastric acid suppression. Clin Exp Allergy 2005;35:245-246. 